\title{
O mundo e o fim do mundo: palavras de um rezador Avá Guarani sobre o desenvolvimento ${ }^{1}$
}

\author{
The world and the end of the world: words of a reciter Avá \\ Guarani/Ñandeva on the development
}

\author{
Yan Leite Chaparro ${ }^{2}$ \\ Josemar de Campos Maciel ${ }^{2}$ \\ Eliezer Martins Rodrigues ${ }^{3}$ \\ Arnulfo Morinigo 4
}

DOI: http://dx.doi.org/10.20435/tellus.v0i0.554

\begin{abstract}
Resumo: O desenvolvimento é uma empreitada conduzida na história por povos agressivos, personalidades que naturalizam os seus atos tornando-o uma espécie de ideal, de boa notícia ou de progresso inevitável. Mas ele nada mais é do que um processo, entre muitos possíveis, de relação entre povos, e entre povos e o ambiente. O que aconteceria se esse processo fosse pensado a partir de outras referências, como das narrativas de povos que não são considerados protagonistas, mas que na verdade possuem um protagonismo mais profundo do que podemos propor com os nossos métodos abstratos e cheios de esquecimentos, invisibilidades e desqualificações? O texto que segue é um passo para responder a uma pergunta dessa sorte. Um discurso Guarani acerca do Desenvolvimento. Uma história que se preserva e que se reconstrói. E que pode ajudar a desnaturalizar algumas narrativas.
\end{abstract}

Palavras-chave: Estudos críticos do desenvolvimento; Antropologia do Desenvolvimento; narrativas; Avá Guarani.

\footnotetext{
${ }^{1}$ Artigo que está como parte da pesquisa de doutorado em desenvolvimento local "O mundo e fim do mundo: palavras de rezadores e guerreiros Avá Guarani sobre o desenvolvimento", conduzida pelo doutorando Yan Leite Chaparro e orientada pelo Prof. Dr. Josemar de Campos Maciel. Construído a partir de encontros com o rezador Cantalicio Godoi nos anos de 2017 e de 2018 no território indígena Porto Lindo (Jakarey) Yvy Katu, guiados e tecidos junto com o pesquisador Avá Guarani Eliezer Martins. Encontros que foram todos regidos na língua Guarani e teve como tradutor para a língua portuguesa o professor de Guarani e filósofo Arnulfo Morinigo.

2 Universidade Católica Dom Bosco (UCDB), Campo Grande, Mato Grosso do Sul, Brasil.

${ }^{3}$ Secretaria Municipal de Educação de Japorã, Japorã, Mato Grosso do Sul, Brasil.

${ }^{4}$ Universidade Federal da Grande Dourados, Dourados, Mato Grosso do Sul, Brasil.
} 


\begin{abstract}
Development is a systematic effort historically conducted by aggressive peoples that try to naturalize their acts by making believe that they produced some sort of good news or some inescapable path towards progress. It is indeed, no more than a process through which people relate to people and towards the environment. One amongst many that would have been possible, in a hypotetical different world or history. What if this whole process was envisaged and planned through other lenses, other narratives and perspectives, namely, that of traditional peoples, that aren't seen in official history as protagonists, but that share an agency and power that are deeper th1111an what our hegemonic and abstract methods are able to create? The text that follows is a step in the attempt to give an answer to questions of that sort. It's a fragment of a Guarany discourse about Development. A history that preserves and redesigns itself. That maybe preserves the power to denaturalize some hegemonic narratives.
\end{abstract}

Keywords: Critical Development Studies; Anthropology of Development; Narratives; Avá Guarani.

\title{
1 NOTAS INTRODUTÓRIAS
}

As palavras do rezador/ñanderu Avá Guarani que seguem foram escutadas, conversadas e textualizadas sensivelmente durante o campo etnográfico e etnológico conduzido por encontros e conversas durante os anos de 2017 e 2018, no território Porto Lindo (Jakarey) Yvy Katu, entre um rezador/ñanderu, um pesquisador Avá Guarani e um pesquisador não indígena. Caminhar etnográfico produzido a partir da aliança de trabalho e amizade entre um pesquisador Avá Guarani e um pesquisador não indígena, que teve como pergunta construída e seguida (LATOUR, 2008) durante esse caminhar, a seguinte questão: o que é o desenvolvimento para os Avá Guarani? Atentos aos sentidos sociais, históricos, políticos e cosmológicos que a pergunta permite seguir.

Questão essa que, nas palavras (DERRIDA, 1991) do rezador/ñanderu Avá Guarani, descobre análises profundas sobre a questão do desenvolvimento, quando perguntado sobre o que é o desenvolvimento para os Avá Guarani, e as relações que eles fazem com a invenção branca de desenvolvimento. Palavras que revelam, com a imagem do mundo e do fim do mundo, organizações sobre a própria noção Avá Guarani de desenvolvimento e as relações de alteridade que os Avá Guarani constroem historicamente em relação à invenção branca 
de desenvolvimento ${ }^{5}$, relações permeadas por conflitos, pacificações (ALBERT; RAMOS, 2002), terror (TAUSSIG, 1993; 2010) e críticas sobre o modo de vida da sociedade "envolvente" (KOPENAWA; ALBERT, 2015).

Para que o leitor percorra por entre as palavras que seguem, adiantamos que, no Brasil unificado artificialmente na história da construção do Estado Moderno, as línguas indígenas são consideradas "estrangeiras" e, por isso, o padrão ABNT exige que as palavras em Guarani sejam grafadas em itálico. Mas o português é estrangeiro aqui. Assim, seguimos o princípio da simetria dos saberes, não aderindo a esse gesto de colonização pequeno, mas substantivo (DELEUZE; GUATTARI, 1978). Esperamos que esse gesto, uma escolha de forma gramatical, mas que possui conteúdo político e epistemológico, faça sentido ao longo do texto.

\section{A REVELAÇÃO DO MUNDO}

Sou Cantalicio Godoi, meu nome tradicional Tupã Ava Veraju; o mato serve para nós para qualquer remédio, para nosso remédio somente no mato, no mato tem ysypo, antigamente nós não usávamos prego, usávamos ysypo, madeira nele tem mel, isso para nós traz benefícios; tem larreina, jate'i, eirusu, eirũ, mandori, tinha neste mato hoje dia já não tem mais. Os remédios tradicionais já acabaram porque os não indígenas mesmo acabaram com tudo. Antigamente nós não comíamos gordura, arroz, nós vivíamos do mato, vivíamos no mato. Trabalhávamos no mato e não conhecíamos os brancos; nós indígenas não vivíamos no meio dos não indígenas, hoje já queremos imitar os não indígenas.

Este mato (canto) o mato tem dono, os nossos deuses enviam água, molham as roças que plantamos e as plantas deles, yvaũ, yvaporoity, tem guavira pytã, yvaviju, pindo aju neste mato; quando está florescendo eles as batizam, e hoje nós indígenas nem mitãkarai já não fazemos. Pode reparar, olha só, o mato traz benefícios para qualquer coisa para nós, mas hoje já não temos mato. Nem um mato já não temos, somente um pedaço pequeno. Os nossos remédios os não indígenas mesmo matam tudo, acabam, os nossos remédios já não saem mais, o

\footnotetext{
${ }^{5}$ Processo de organização conceitual construída no trabalho de pesquisa de doutorado em desenvolvimento local "O mundo e fim do mundo: palavras de rezadores e guerreiros Avá Guarani sobre o desenvolvimento", conduzida pelo doutorando Yan Leite Chaparro e orientada pelo Prof. Dr. Josemar de Campos Maciel.
} 
capim mata eles. Somente para as comidas dos bois os brancos plantam. O mato é muito proveitoso para nós para muitas coisas.

Este foi onde eu plantei rama de mandioca. Este que foi roça de mandioca já tem 20 anos. 22 anos. Ainda tem mandioca, este foi que eu plantei, aqui tem ysy, aqui tem muito yvaũ do mato que eu plantei. Não é yvaũ dos brancos. E nós somos pela terra. Olha só, hoje já não tem quem reza para o Tupã, talvez precise muito tempo para poder contar. Mas ali já mente. Já só tem conhecimento de mentira só a cachaça que a conta. Já não mais o tupã. Eu rezo para os taruágui, do vento surgiu, nossa alma, os corpos que foram abençoados pelos nossos antepassados; eu já tenho 63 anos no meu corpo ainda não sinto nada, trabalho muito bem, faço carpida, carpida ainda faço muitas coisas. Mas tem muito de nós que já não, porque olha só o que foi feito pelo branco, a cachaça deteriora nosso corpo.

Muitas crianças hoje já não vivem, e eu ainda vivo e me sinto bem e vou viver mais tempo, muitos vão me felicitar por minha idade de velho, ou vou ser um peso para as pessoas. A nossa própria família tem alguns que não se sente feliz por nós velhos, porque já não morreu esse velho, dizem. Então o mato é muito proveitoso para muitas coisas, para construir casas. Antigamente nós não usávamos prego, eu fiz do pindo, do pariri, do jahape, do iguíra (caraguatá). Presta atenção, Tupã conta quando a granizada vai cair, aos rezadores ele conta; se preparem todos, cuidado que vai vir vento forte. Hoje em dia não tem ninguém que conheça.

Hoje a bíblia, o papel, por aquele satã, que matou o Deus, todos caminham atrás dele, mas nós não somos brancos, não somos, nós somos do mato. O nosso Pai tinha nos batizado no mato, nos batizou junto com o mato, no meio das frutas, alcançou todos os que estavam no mato. E hoje não tem ninguém que reza e conta para nós essas coisas, já não tem. Já não tem a nossa dança, acabou. Porque quem está crescendo e começa a ler já passa para ele a bíblia, "aqui tem a bíblia pode ler, com esse vai alcançar a deus", diz. Nós nunca vamos alcançar nosso Pai, o Ñanderu não foi ele quem rezou a bíblia, o nosso Ñane Ramõi e o Ñanderu fez brilhar pela Virgem de Caacupe, e por isso que ele fez todas as coisas. Fez levantar o que ele plantou, mas que ele não vive como nós vivemos. E se alguém diz que nós alcançamos o nosso Ñanderu isso é mentira, e nós faz mal, hoje não tem rezador novo, quem dança verdadeiramente, já não tem quem toca o takua, até as velinhas vão com a sua saia comprida na igreja evangélica e isso não é nosso. 
Ainda tem, eu sei fazer o arco, também faço flecha, só que tenho muito trabalho. Faz do takuapi. Do takuapi, só se encontra lá pelos gasory. Por isso que o mato e importante para nós, lá tem fibra para fazer cesto, yrupẽ, tem para fazer o arco, a gente não usava colar, era o arco que nós usávamos, o que a gente procurava são os pássaros somente, no mato tem bicho e nós vivíamos deles e hoje já vivemos dos venenos, os porcos das granjas são a base do veneno. E se prestar atenção pelos animais que vivem no mato, eles vivem como nós também, vivem mal. Vivem só em um pedacinho de mato.

Aqui mesmo vive muito tatu, sai até aqui, só que nós não comemos, pois ele já vive mal como nós. Já temos pena deles para matar. E hoje no meio de nós já temos vários professores, professoras, já tem quem estuda para médico, já temos enfermeira, as pessoas indígenas que estudam, então o nosso jeito de ser já está ficando para trás e o mais antigo já fica para trás. Nós que somos velhos já não vemos mais acontecer nada, e por isso, olha os Tupã, como eles estão, eles ainda dançam, dançam, quando se levantam. E vai voltar de novo os nossos Tupã, depois do frio, quando passa o frio, eles vão mexer no mato. Pode se cuidar porque vai derrubar casas, vão vir eles, se preparem todos, podem gritar ou podem tirar para fora a bíblia, só que menos de um minuto já vai cair o relâmpago por eles, e eles não querem ver a bíblia, porque não é deles isso. Porque ali a gente tem perigo dos nossos Ñanderu. E quantos dos nossos parentes vão morrer, mesmo assim.

Esta terra é muito útil para nós. É útil para muitas coisas. Para falar bem, esta terra, à terra, por nosso corpo nós plantamos muitas coisas. O que pode, esta terra que pisamos, é muito útil para muitas pessoas. Mas quando comemos por nosso corpo, e o mesmo que plantamos por nosso corpo, que Nandejára faz crescer o que nós plantamos. A terra é muito útil para muitas coisas, traz beneficio para que nosso corpo possa comer, e o que plantamos também cresce. O que cresce ele dá de comer novamente. Quem vive e se levanta ele mesmo dá de comer, ele mesmo come de nosso corpo; então nós que somos humanos, esta terra tem seu dono, tem dono, e se nós não rezamos ao dono, só andamos por andar. Como o mbutu sem olho atropelamos o que está na nossa frente, e não nos juntamos para dançar, não conversamos uns com os outros, e por isso que andamos mal. Não falamos que estamos indo bem. Anteriormente a nossa alma, espírito era limpo e, depois que a terra ficou toda ensanguentada, hoje andamos mal. 
Presta atenção, este é nosso corpo, a terra, tem espírito, porque sem espírito nós nem vamos levantar. Aquele Panambi tem pelo menos seis metros anda acima da terra, ele não fica perto de nós porque a nossa carne tem mal odor no sangue, as pessoas de mal fazem qualquer coisa ruim, ele não pode ficar perto, e ele leva o nosso canto, ele quem leva, ele quem atende pelo espírito, esse pássaro é a beija-flor, ele é enviado por Tupã, ele vem e se veste como mulher, as mulheres que estão grávidas têm dois espíritos, têm o espírito da sua mãe e o espírito da criança. Vivem dois, só não fica neles, vive acima, mora no alto. Porque não pode ficar pegado porque o nosso corpo está sujo. Não podemos dizer o meu corpo está limpo, nunca. Todos têm espírito, porque sem espírito não podemos viver neste mundo. Seja quem for.

O espírito mesmo tem uma luz, porque antigamente quando caminhávamos pelos trieiros, hoje temos caminhos bons, pelos bosques, cheio de taquarinhas, de taquaras, caminhamos pelos trieiros, a luz é vista desde longe, e é por isso que as coisas ruins, os donos da noite, os póra, os que não enxergamos, eles se escondem porque têm medo daquela luz, porque eles não têm isso. Isso são as que já morreram. E as que vivemos está acima de nós. Todos, não somente nós, todos que vivemos na terra, isso nós temos; e os crentes dizem que as pessoas que vivem sem preocupações eles não têm espírito, como é que não vamos ter? Nós mesmos somos demônios, a gente faz todas as coisas, queremos dinheiro então vivemos no inferno, queremos dinheiro e hoje já queremos as coisas que utilizam os brancos.

Já não utilizamos takua, já não usamos mbaraka, casa e chicha, todos eles, já não trazemos na nossa casa, nem no porongo para ter a chicha, nós dizemos na nossa língua kaguijy, aquele rora, tangu'i, kaguijy, já ninguém come, chipa guasu, chipa tanimbuguy do milho, só essas coisas antigamente nós comíamos. Comíamos com a chipa o guembe, tem ali, ainda verde, esse as mulheres cozinham assado, isso não tem que morder porque ele tem algo que coça; então os de antes viviam de isso e é por isso que vive até 125 anos; e nós hoje já não, porque a nossa própria comida deixamos de lado.

Deixamos de lado. Olha um pouco tem a nossa comida mborevi kyra, akutipáy kyra, kuati kyra, mbuku, takuapi raso, essas eram os nossos aceites. E esses estão no mato, no mato mesmo. O mato é importante mais que o nosso patrão, 
o nosso grande patrão é o mato porque ali tinha de tudo, antigamente, mas que agora já não tem mais. Hoje não tem nada. Nós somos diferentes, a nossa cultura é diferente. Eu escuto o que o mboraéi fala, isso é o nosso, isso que é nosso mais que hoje ninguém escuta mais. Já ninguém escuta o mboraéi, tinha um ruído grande.

Já ninguém dança, por quê? Porque vão todos atrás dos crentes. Isso é o que nos faz mal; olha um pouco, antigamente, os jovens, meninos e meninas, tinham quem está começando a cantar, quem tocava o takua, quem conta o que vai acontecer, que vai fazer os Tupã; eles contam para que as mulheres se preparem porque eles vão se levantar. E hoje vivem nas obscuras; uma outra vez estavam todos possuídos e eu estava embaixo da minha casinha, levantei bem cedo, estava tomando mate e, depois, começou a relampaguear e vi duas pessoas correndo com a lanterna, foi uma da minha filha, ali o marido da minha filha, e falou para mim: já levantou? Já levantei, falei para ele. Estava tomando mate: venham vamos tomar mate. Estava amanhecendo, ainda não saiu o sol. Então, onde estão indo, a Irma está doida já está morrendo, a minha mãe quer que você vá para vê-la, diz para mim.

Pegaram ela pelos dois braços, ela estava se mexendo muito. Estava possuída por o dono da noite. O espírito do mal. Depois de três vezes do meu sopro, caiu nela a luz, e ali ela se acalmou. Se acalmou e soltaram ela. Os nossos Ñanderu que soprou ela. Mas o que caiu a luz nela era bem branca. Depois foi de novo, já amanheceu. Já amanheceu quando foi na minha casinha. Depois dessa manhã, fui para ver; se tinha se levantado bem, e já estava bem novamente. Se fosse por eles, já estavam jogando fora ela; eu disse. Se eu não fosse um rezador e já aconteceu com três pessoas aqui. Por três pessoas aqui mesmo.

Eles me aprovaram e ficaram com medo, mas me aprovaram, mesmo com medo; não ficaram com medo de mim, ficaram com medo do Tupã, não de mim, eu não sou nada, tenho só meu corpo, tenho os nossos Ñanderu quem me ajuda; tem quem acalma eles, não sou eu. Apenas sou um instrumento, instrumento dos Tupã. E hoje já não tem um quem é instrumento ou enviado por Tupã, já tem pouco, pode ter em alguns lugares. Mas hoje também os Tupã se sentem longe de nós, porque nós não vivemos como deve ser, alguns só fazem e não é verdadeiro. E é por isso que não a vestem com a sabedoria por eles. Porque eles, os Ñanderu, eles têm a sabedoria. Tupã Ñandejára a quem se escuta longe, que está no lado 
ao pôr do sol, tem quem está ao leste, ao sul, ao norte, tem quem é abençoado que vive no mato, eles estão nesses lugares.

Como a água. A água é muito importante para nós. Para que vivemos acima da terra, não só para os indígenas para todo o mundo. A água é como a nossa mãe, a gente tomou peito, e nós falamos que desmamou, não, porque não podemos viver sem a água. Não podemos viver sem a água, nós falamos que desmamamos, mas não dá água. Podemos reparar pela criança; ela não toma a água pura, mas ela toma o leite materno, nós dissemos que não toma água, mas ela está tomando junto com o leite materno. E nós falamos que, depois de crescer, que já desmamamos, não, o que fica no lugar do leite é a água.

A água é a nossa mãe, a mãe de todos, não só de um, de todos os que existem no mundo. A água é a nossa mãe, sem ela não existimos. Usamos para tudo, comida, para batismo, para o batismo da criança a água é o principal. Sem a água, não vivemos nem um dia, eu não ando sem a água, sem beber, nem uma pessoa pode dizer que não usa a água. Eu sou quem já desmamou, isso eu fiz. Porque a água serve como se fosse o leite, para todos e não só para um. Não tem ninguém quem fala que não bebe água.

Da água, os brancos põem energia, eles instalam energia, a que nós usamos está no Foz do Iguaçu, no Paraná, eles usam a energia por meio da água, eles chamam a isso desenvolvimento. Para eles é dinheiro, instalam na sua casa a energia, e eles querem dinheiro. Todo isso eles a chamam de desenvolvimento e nós não. Nós somos diferentes. Somos diferentes. As crianças pequenas, a mãe dá banho na água limpa. Põe para ela água morna para tomar banho desde pequenininha, não toma ainda porque é pequena ainda, toma no peito da mãe, o leite. Nós dizemos que não toma água, não, ela toma sim. Ela está tomando indiretamente. Tudo isso hoje, ninguém mais sabe.

E o vento, olha bem, por causa do vento o nosso corpo caminha. Se você vai dois metros num buraco onde não tem vento, o que a gente respira já vai acabar. O vento nos ajuda, a gente se levanta com vento, o nosso corpo, o nosso sangue, o vento nos ajuda. Isso não pode estar contaminado. Os brancos usam veneno e isso vai pelo vento, eles usam avião.

A gente também é contaminado pelo veneno, da gripe, da dor de cabeça, dor de olhos, dor nos ouvidos, por causa do veneno. O vento que traz. O vento, 
ele não tem culpa, não tem culpa, porque o vento ele se origina no mar, dali que ele vem, porque o mar atira tipo uma fumaça; uma nascente é onde o mar está respirando, eles através do vento trazem frescura, os animais vivem mediante o vento. Presta atenção, se o vento parar um pouco, já molesta a gente. Todos os animais e todas as coisas vivem por meio do vento. Não só para nós, mas sim, para todos é importante o vento. Porque ele refresca a terra, e a terra está acima da água. Acima da água. Nós falamos que o sol que se movimenta, não ele não se movimenta. É a terra que se movimenta, presta atenção, os relógios também trabalham pela terra, e assim que a terra se move e nós não a sentimos.

Quem sabe aonde a gente vai se encontrar em uma tarde, a terra gira completamente, a gente não sente, aquele sol e a lua não se movem, somente a terra é quem gira. Então a terra tem onde se apoiar. Está assim. Uma pedra. Aqui está o cupim, e acima dele a terra. Acima deste está a terra, e aqui é toda a água. Ao redor e toda água. Então isto fica embaixo da terra. Acima deste, está a terra o que o Ñanderu fez. Então este é quem gira, gira totalmente. Nós dissemos que esta classe é grande, não é grande. Este é quem gira, e ele não pode ficar porque está acima da água. Acima da grande massa de água. É por isso que se move, o sol não se move, a lua não se move, só a terra. O cupim está comendo a terra, aqui também. Por essa razão que nós indígenas temos que voltar a rezar e dançar para que possamos assegurar novamente.

A outra vez construíram a casa de reza, mas quem fez, foi só por fazer. Fizeram lá no fundo, longe da casa de quem conhece, não foi quem conhece que fez, eles não fizeram e ficaram de novo de fora. Não tem quem reza e quem vai contar. $E$ deixa de lado a casa de quem conhece, do rezador. Faz em qualquer lugar só por construir. Nem perguntam, só constroem porque veio um recurso, constroem e talvez como é de fora, pode ser que põe algo dentro de seus bolsos, sabemos de isso. Por isso que não se dança mais. 
Foto: O Mundo. O Fim do Mundo. Porto Lindo/Yvy Katu.

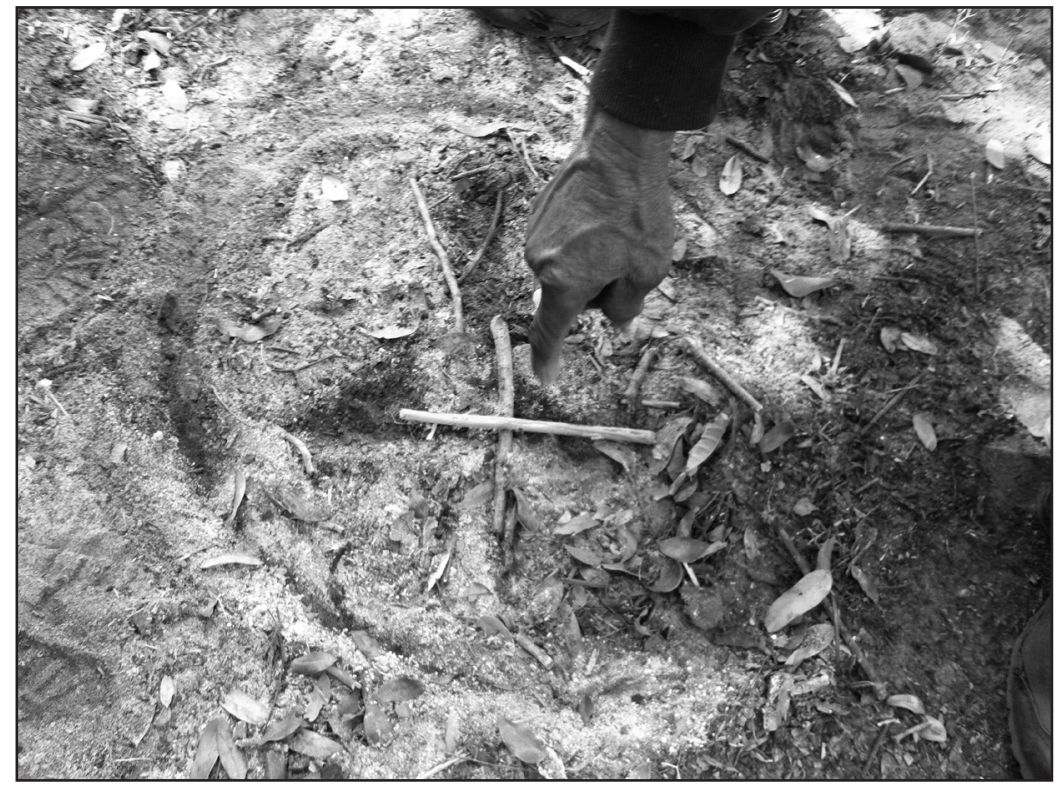

Fonte: Acervo pessoal de Yan Chaparro, 2017.

Já está comendo deste lado e aqui deste lado também o mesmo, já os quatro cantos está comendo, e já está pegando água. Então eu mostro tudo isso, mas não temos um rezador para contar isso, ou os Tupã para falar disso no seu sono, já não tem. porque os Tupã se fazem corpo para poder contar a seus rezadores, porque eles dizem Ñamõi aos rezadores. E hoje já não tem ninguém, e é por isso que nada se perde de mim. Nada se perde de mim. Até hoje eu estou pronto com os Ñanderu, eu não faço de lado nem um pouco, e eu vou morrer assim.

Ainda tem possibilidade. Olha bem, tem remédio para quem fica doente da cabeça, está na pedra, ali tem remédios de toda classe, goteia água dele. Lá no gasory tem uma pedra, nele tem só remédio só por ele goteia água, está no último. Isso a gente tem que trazer no batismo das crianças para batizar as crianças. Estamos entrando em tempo para plantar várias plantas, e batizamos com nomes tradicionais, isso é importante para nós. Hoje já não é batizado dessa maneira, já

${ }^{6}$ A situação do mundo hoje. Sentida, percebida, profetizada e pensada pelo rezador Cantalicio Godoi. 
vão com a bíblia na mão para o rio com os brancos, e isso não é nosso, a gente erra nesse sentido.

Presta atenção como os crentes vivem, eles não respeitam família dos outros, não respeitam casa dos outros, não respeitam a mulher dos outros, não respeitam nada. É por isso que eu mandei fora todos daqui, porque para mim é ruim isso. Então falei que aqui já não pode mais. Tinha vindo aqui, e depois mandei fora daqui. Porque eu sou daqui mesmo, sou daqui, entrei quando tudo era mato, já faz 52 anos que estou aqui, tudo isso foi que eu plantei, rama da mandioca, feijão andu, entrei num roçado, não tirei as árvores, tinha muito guaporoity, ali tem uma planta ali.

Eu quero que vocês escutem muito bem, porque o que eu estou contando é muito importante. Eu já procurei muito do porongo pequeno para fazer a minha mbaraka, e até hoje não consegui encontrar. E os Ñanderu querem porque eles vão chegar um dia. Eu não procuro no bolso dos brancos para poder cantar ou rezar, porque eu conheci do próprio Tupã, e não é do bolso dos brancos que vou tirar e mostrar aqui tem versículos para dizer, não. Eu tenho no meu coração, eu tenho na minha frente um espelho bonito, e não é livro. Eu não procuro em nem um lugar, eu tenho no meu coração. Até aqui eu vou contar para vocês, porque para nós tudo isso é importante, para a gente fazer enquanto vivo, ainda porque eu já sou velho. E hoje em dia já não tem quem pode contar, já não tem, pode procurar em qualquer lugar, já não tem.

\section{O CUIDADO COM O MUNDO}

Cantalicio pronuncia um canto. Agora vamos continuar nossa conversa sobre a água, mato; a água tem o seu dono, o karumbe é dono da água, o jakare é dono da água, sukuri é dono da água, mbói jagua é dono da água, e tem dono que não vemos igual como uma pessoa, só que não a vemos são esses que cuidam do animal porque se mata um karumbe, ele tem dono, ele cuida dessas, só que a gente não a vê. E tem muita pessoa olha só o animalzinho, aquele que caminha acima da água, o animalzinho, esses são que ficam acima da água, esses não são os donos da água que se alimenta dele tem outro, tem kuarahy mimby, tujuju, guasu oko são comidas deles e não é dono da água. 
Eles querem ser quem conhece mais, mas não conhecem, são só alimento para outro. Se alimentam dele tujuju, kuarahy mimby, guasu oko, tem na água tajasu guyra, são alimentos desses. São alimentos que recorrem a água. Não é dono da água. $\mathrm{O}$ dono da água a gente não vê. O dono da água, que cuida da água, karumbe, jakare, sukuri, mbói jagua, mbói ro'y, tem outro animal, carpincho, tem também o lobo, tem bobope, bolo pytã, e tem lobo marinho, então eles são os donos da água. São eles o dono da água e não é ñetĩ'i. Porque aquele ñetî́i tem quem se alimentar dele; esses pássaros kuarahy memby, tujuju, tajasu guyra, eles se alimentam disso. São comida dele o ñetî́i. Não é o dono da água, o dono da água a gente não a vê.

Quem cuida da água são esses animais que falei. Ele errou aí, errou aí. Quer ser quem conhece, mas que não sabe nem um pouquinho. Porque eles não são rezadores, mais que mais ou menos vão por aí; eles acham que é assim. E não é assim, não é assim. Primeiramente é difícil entender as palavras deles, falam bem baixinho, através da sua palavra já vai compreender que está mentindo. Porque quem está mentindo a gente se dá conta. Aquele que ele contou tem quem se alimentar dele, se desce, aí rapidamente vai ser comido. Um ou dois se desce vai ser comido rapidamente; comida dos pássaros; é comida deles, o ñetî́i tem quem come ele.

O dono da água nós não vemos, o dono da água quem cuida mais da água são karumbe, sukuri, mbói jagua, e quem se alimenta acima da agua são tujuju, kuarahu mimby, tajasu guyra. Eles não ficam onde está seco. Nós, os Avá Guarani, nós cuidamos de todos eles, dos pássaros e da água. Porque a água tem o seu dono, e porque tem dono ele está aí. A nascente existe porque sem os donos da água, a nascente não iria estar aí. O dono verdadeiro da água nós não o vemos.

Nós, os Avá Guarani, nós cuidamos da água para não ficar sujo, porque antigamente nós tomávamos água em qualquer lugar do mato, a água era muito fresca porque tudo era mato, e hoje já não é assim; hoje até as vacas fazem xixi nesses lugares, os cavalos, e fica uma muito ruim, não podemos cuidar, porque os fazendeiros não deixam a gente entrar nos lugares. E agora com o nosso tekoha Yvy Katu, temos muitas nascentes muito bonitas, tem muito. Quem fica em Yvy Katu precisa cuidar das nascentes, tem que limpar as nascentes para que não se tampe.

Nossas danças ajudam a gente também. Os Tupã, hoje, já que você falou de lá do norte que ele veio, têm um portão negro de onde veio todos com takua 
(bambu) dos Tupã; não vai demorar para chover, não vai demorar. Precisamos cuidar da água como esses pássaros que cuidam também, porque esses pássaros cuidam da água. Para que não fique sujo, o nosso Ñanderu põe para esses animais pequenos outros para que cuidem de isso. Eles não saem do lado de fora, só vivem perto das nascentes. Se acaba a nascente, eles mudam para outro lugar. Vão para outro lugar, para uma nascente limpa, e cuida. Porque a água serve para todos.

Contei outra vez, quando a gente é criança, a gente é desmamado, e o que fica para nós, como nossa mãe, é a água. Fica como a nossa grande mãe, até a gente morrer. Mesmo se já não caminha, necessariamente tem que beber água. Vai ter que tomar água, isso que ficou no lugar do leite materno. Não tem nada que substitui a água. Tem o pez eles cuidam da água, limpam, comem os bichinhos que tem acima da água, e tudo o que corre na água eles fazem comida deles. Eles são para isso mesmo. E nós também precisamos prestar mais atenção e cuidar da nossa água. Também precisamos cuidar dos pássaros, antigamente a gente só matava; tínhamos o arco e matávamos lorito, gua'a, meimbe'i, arua'i, chi'óro, a gente matava tudo que a gente encontrava. Mas hoje já não podemos viver assim. Porque igual como nós, os animais também vivem hoje em um chiqueiro mal. E precisamos cuidar dos animais. Olha só aqui tem muito tatu, aqui tem muito. Precisamos cuidar.

Os brancos não cuidam da água e nem deles. Os brancos põem canos embaixo da terra e os animais pisam todos quando encontram. Nós nem podemos mais cuidar porque os fazendeiros fecharam tudo com cerca. Os bichinhos não são nada para os brancos. Eles, os brancos dizem, isso não é nada, não é nada. E nós que vivemos na terra Avá Guarani. Eu quero que vocês façam porque já tenho 63 anos, já sou velho, que façam um documento disso para que não acabe. Porque quem conhece tudo isso já não existe mais. Agora de onde você (Yan) vem, do norte, deve contar igual como estou contando. Mas não com a mesma forma para eles, porque não tem reza.

A chuva que nos ajuda, a água é quem ajuda para que possa ter flores, para que as frutas madurarem, tenha fruta. O Ñanderu quem batizou com a chuva todos, e não um por um. Se vier do nascer do sol, o Ñanderu vai estar na frente rezando, e atrás dele já vêm a chuva. Só que pega todos, e nós também somos assim, o nosso Ñanderu nos batizou no mato, nós, os Avá Guarani somos do mato 
mesmo. Podemos ir de avião por aí, mas somos Avá mesmo, você pode ser no avião, mas você (Eliezer) vai continuar sendo indígena. Não vai poder se esconder.

Porque já fomos batizados; e quando esta terra já foi destruída, o nosso Ñanderu mesmo fez o tacuru, e ele escapou embaixo dele. Nós somos da terra, somos nascidos da terra; então hoje já não tem ninguém que conhece isso. Vocês chegaram em lugares onde tinha confiança, mas quase nem falaram para vocês. Porque eles não têm coração para falar.

Com a água também batizamos as crianças, isso é o Ñanderu que faz, para a gente se sentir forte. E para pôr o nome na criança é preciso que o Ñanderu dê o nome no sono e não é só da nossa parte. Só assim que vai ter a benção aquela criança. Antigamente se rezava dois dias para que possa ser batizada a criança. Só come tangu'i, rora e outros, as coisas doces não come; manda trazer jate'i, larreina, se vai comer coisa doce. Porque isso é limpo, são das flores das árvores, não é como hoje em dia. Porque de todas as árvores que tem, do mato ele faz para sua panal e depois o mel.

Tudo isso já foi batizado, larreina, jate'i; e por isso que nós vivemos mais tempo do que os que vivem hoje em dia. Porque vivíamos assim. Era tudo mato, tinham muitos animais, larreina, tinha de tudo, mas agora já não temos mais. Já não temos nada de mato, só um pedacinho de mato que sobrou. E nós precisamos nos esforçar de novo, agora vai cair o tatatina. Nós indígenas temos que usar o adorno de aves, Avá Guarani. Hoje vieram muita gente de lá, todos são de itakua, vieram junto a mim, só que eles todos tinham pano na cabeça. Adorno na cabeça de aves, hoje nós não usamos mais. Agora vai ser tatatina, e vai acontecer que vai cair pedra por aí, vai cair árvores.

Mas vai ter crianças que usam arco, vão praticar, brincando. E nós precisamos usar o adorno de aves para que eles possam nos ver. Usamos a vara para se defender, a gente põe na cintura das crianças. Pelo menos no braço a pena de uma ave, mas hoje a gente não usa mais. Tem pouca gente que usa, e é preciso um esforço para usar novamente. Temos que esforçar para que aqueles quem não vê a gente, enxergue novamente. Nós ficamos na escuridão. Na escuridão.

Temos também que cuidar do mato, porque o mato puxa água, puxa também a água. Presta atenção, agora vai florescer e depois vai chover, ainda não desceu o taguato hovy, ainda não desceu tingasu, glaviota, surei, suiriri, guyra hovy, ainda 
não desceram, mas agora vai cair o vento para que eles possam vir, vai descer na terra, para que possam se criar; porque onde eles vivem não tem lugar para que possam se criar. Eles moram no céu. Estão se preparando para vir, para o Tupã preparar eles, e vai trazer eles. Eles têm dono.

Para as crianças receber o nome, tem que preparar para que possa ter o nome verdadeiro e para que possa ter saúde. A filha da minha filha que mora aí, o nome dela é kuña Amba, quer dizer mulher pequena. Toda a minha família tem nome, a outra tem nome Tukãmbi, Kuña Amba, Kuña Takuaju, cada um elas têm o seu nome. Não foi eu que dei o nome, foi o Tupã quem deu os nomes. Ele que dá os nomes para todos. Dá o nome de lá de onde nasce o sol. Não somos nós que damos os nomes. É Tupã.

O Tupã quem deve dar o nome, antes de dar o nome, o Tupã já sabia. Foi Tupã quem deu esses nomes. Agora já é de idade, tem uma moça, um jovem, tem só dois. Então hoje já quase ninguém conhece mais isso. Se por aí alguém passa para ela um litro de pinga, ela vai ficar rindo disso. E quem é sério e lembra do Tupã, quem lembra da terra, não aceita. Dificilmente quem não é rezador que conhece isso.

Existe também o dono do mato. $\mathrm{O}$ dono do mato a gente não vê também. Quem cuida do mato tem jaguarete, dono do mato; tem o porco do mato também dono do mato; tem tajy katĩ também é dono do mato; tem akutipáy também dono do mato; tem akutĩ as'yju também dono do mato; tem ymykurẽ também dono do mato. Porque eles vivem no mato; e quem cuide deles, isso a gente não a vê. Somente quem é rezador pode classificar. As crianças precisam conhecer isso, porque quem conhece isso já vai acabar.

Se uma criança, alguém for no mato, antigamente, guaporoity verde não pode mexer por mexer, porque isso tem dono, tem que esperar que madure primeiro. Agora vai florescer. Vai florescer guavira pytã, guavirami, ñanduapysa, guaporoity, yvaũ, jarakati'a, gueimbe, yvaviju, todo isso vai florescer já com aguyje, aguyje quer dizer todos. Hoje estou contente por vocês (Eliezer e Yan) terem vindo, e eu estando vivo ainda. Porque sempre cuido da minha família. Os pássaros se alimentam das frutas maduras, porque se o mato acabar eles vão ficar sem jeito, vão ficar todos mal, e podem ir embora também.

Tem também guavirami, tem nosso remédio como kangorosa, tem jate'i ka’a, ñandu ka'a, ynambu putã ka'a todos são remédios. Todos são nossos. Nós 
Avá Guarani usamos tudo isso, como o guavirami, porque ele é remédio para tye ruguy, ñanduapysa é para dor do ouvido, então isso já não tem quase ninguém quem conhece.

Como a gordura do macaco, essa gordura é um remédio forte. Olha só o macaco tem santo, todos querem ver, se esfrega numa menina, vai ser bom demais, em qualquer lugar só por ele mexer com o olhar das pessoas, os homens porque ela tem nela o remédio da gordura do macaco. E também o mesmo acontece para nós homens se for usado como remédio. Mas hoje nem o macaco já não tem.

Essa é nossa maneira de viver. Não vamos encontrar outra maneira, isso é nosso mesmo, a dança com o takua é nosso; o vento serve para tudo, presta atenção pelo peixe, ele vive na água, e o vento passa acima, mas ele tem onde guardar o vento, então, cada vez que acaba o vento onde ele guarda, tira o nariz para afora e carrega de novo de vento, e quando já encheu entra novamente na água.

E a gente? O nosso motor, nosso coração, ele trabalha pelo vento, o vento é quem dá força para ele. A comida que a gente come serve como se fosse um combustível como usam os carros, porque, se nós não comemos, ficamos fraco, o nosso corpo fica débil. O vento é quem dá força para o coração trabalhar, porque a nossa pele tem poros, e o vento entra por ele; é como se for água para nosso alimento, e se transforma em sangue e nosso coração trabalha por meio do vento. E quantos fios temos aqui, as veias, e todos estão por ele, todos estão pelo nosso coração e igual que um motor pequeno; quantos quilos de carne o coração faz trabalhar, quantos quilos de carne ele move, a nossa veia percorre por todo nosso corpo, mas ele faz trabalhar tudo, como um motor. Então o vento é quem ajuda o nosso coração. E o alimento que a gente come é como se fosse combustível. O vento também ajuda as árvores. E as árvores dá para nós, para usar no fogo. As melhores árvores são yvyra jepiro, piti'ỹ, yvyraovi, yvahái, kupa'y, são do mato, todos são para lenha e madeira boa. Isso que a gente usa.

Tudo isso que contei, a gente precisa ensinar novamente para as crianças. Temos que ensinar. Temos que fazer uma casa de reza, para que se reúnam na casa de reza, para que possamos conversar com elas, contar para elas, somente assim, pois do contrário vai acabar. Já está acabando né. Então isso que falei, fizeram casa de reza lá no outro canto, não sei onde mesmo, e ficou parado, pode 
ser que um lagarto passe por aí, quando for o tempo dele. Ficou parado. Se a gente não tem tudo isso, somos e ficamos pobres. Os não índios são diferentes, eles têm que ter muitos bois, tem que ter vários caminhões, tem que ter avião, assim que eles se levantam e se mostram para nós, mas a gente não.

O meu nome é Cantalicio Godoi, e meu nome tradicional é Tupã Ava Vera Ju, o meu primeiro, meu nome tradicional. Quando eu tinha dez anos, já comecei a rezar, bem antes dos não índios entrarem aqui no nosso território. Para o batismo da criança eu vou contar, tem yary (cedro), a água do yary, o que foi feito das abelhas, chicha feito do pindo aju, para tomar, tem avati morotĩ, avati mitã, mandioca que era nosso, que trouxe o Tupã, mandi'o karape como se diz, ele é baixinho mesmo. Tem tudo isso.

São esses para preparar e para fazer o batismo. Foi Tupã que trouxe tudo isso bem antes da gente estar no mundo. Mandou trazer a flor no hu'y ao nosso Ñanderu quando pediu para ele. E isso eles fizeram germinar as árvores, eles derramaram do hu'y na água e, depois de oito dias, já começou a nascer. Mudaram para a terra e vão reproduzindo isso. Agora até isso já é dos não indígenas. A nossa mandioca é totalmente diferente. Mandi'o karape ele tem a raiz redondinho. Aqui que eu plantei nem brotou ainda, então para mandar trazer isso, não tem mais. Avati morotĩ puku, kumanda puku somente o Tupã trouxe a flor no hu'y, e hoje já não tem mais. Até isso acabou. O que Tupã trouxe acabou. Nós perdemos tudo isso. E os não índios, eles não perdem, eles guardam pra eles o que é nosso, e nós não.

Aipo pyve.

\section{O MUNDO E A IMAGEM DO FIM DO MUNDO}

Porque quem, a terra, nós falamos que o sol que caminha, o sol e lua não se movem, não caminham, elas estão em seu lugar; a terra é quem gira, gira desse modo. E nós não sentimos que a terra está girando. Nós falamos que o sol que se move, mas a terra está acima da água, embaixo da terra tem muita água. Pode ver que os aparelhos que colocam embaixo da terra, embaixo de nós; embaixo de nós tem água, vivemos acima da água. E por isso que a terra, o sol e a lua parece que se movem, mas é a terra que se move. Pode prestar atenção pelo relógio feito pelo branco, esse relógio move uma hora, e nós não enxergamos, a terra é assim também. 
Cada amanhecer a gente nem sabe onde que amanhecemos, mas nós não percebemos. Para nós o sol que move, a lua que move, mas então se movem; é a terra que se move. A terra está acima da água, e é por isso que nós sentimos a terra por estarmos acima da água. Podemos prestar atenção, quem está acima da água, elas põem assim, e acima disso ela põe a terra e põe seu ninho porque assim água sobe, ela sobe sozinha, ela não fica embaixo da terra. Porque ela põe acima dela as folhas secas e, acima disso, põe terra para que possam os filhotes botar ovo ali e, se a água sobe, ele não se sente perseguido porque, se a água sobe, ele também sobe, nunca ele afunda. Ali ele põe ovo e nunca se afunda, porque põe as folhas seca.

Para nós, a terra está assim, a madeira está cheia de cupim, já está comendo tudo por cupim. Pode ver hoje a terra, diz que reza, já ninguém respeita a terra, os nossos antepassados (deuses) já estão matando nós, eles estão nos castigando. Porque nós, por causa dos crentes, eles não são parte de nós. O que é nosso, nós temos que dançar, rezar. Os não indígenas não podem continuar porque só sabem fazer com papel e, por isso, o nosso canto é o que brilha o relâmpago. Mas hoje em dia já não tem quem reza pela terra. Só pelo papel, pode ver, uma criança, você dá um papel para ler, e ele vai ler rapidamente. Porque nós que somos indígenas, todos poderíamos rezar se o nosso grande pai entregasse o seu poder, mas não para qualquer um, porque qualquer não pode rezar. Só nós, mas os crentes trazem no papel, desde pequeno já apreendem porque isso já está no papel. O que é nosso é o que é de verdade, que é da terra, e é isso que temos que escutar isso não tem em nenhum lugar. Em nenhum papel.

O que é nosso é o mesmo que o relâmpago dos Tupã, é nosso e é deles. Nós somos assim hoje, porque até as anciãs já vão com a bíblia na mão. Já não pegamos o mbaraka, já não usamos a akãnguaa, takua, já não a usamos mais. E por isso que Tupã nos está matando e vai ir matando mais, lembre-se de mim; depois vai vir vento forte, vai tirar do chão as casas dos brancos, antigamente fizeram da fibra de caraguatá para que, quando caía a granizo, não perfurava, só caía e ficava branco o teto da casa, e hoje os brancos fazem de pedra, de pedra; mas, se vem a granizada, perfura tudo até cair, porque eles não respeitam. Aquela casa alta de vários prédios. 
Quer dizer que eles querem ser mais inteligentes que o nosso Deus, que o nosso criador, eles querem ser mas inteligentes. Nosso Deus manda granizo, mostra o que ele é para os humanos, os brancos; eles aparentemente não têm pressa, porque suas casas são bonitas, aparentemente. Mas para o nosso Criador isso não é nada, e por isso que manda raio e inundações. Os carros ficam todos no chão. Isso quer dizer Tekoaã. Para ver se eles compreendem. Esse canto é quando vem um vento forte. Cantalicio canta. Quando a gente ergue a cabeça, eles já enxergam nós, porque nós não nos escondemos deles, nem um pouquinho. Com aquele espelho grande, ele nós vimos a todos. Por isso que nós rezamos, dançamos, cantamos. Os deuses nos respeitam porque as coisas deles nós levantamos para eles.

E por aquele livro, pela bíblia, não podemos demostrar porque vai ser como relâmpago posto na nossa cara. E, muito rapidamente, eles tiram o nosso canto de nós. E se eles nos matam, a gente não vai para nenhum lado, a gente se queima tudo; a gente não se salva, porque eles nos tiram da terra. E por agora já não tem quem reza ou comenta estas coisas, os de antes já não tem ninguém; algum senhor ou senhora, aparentemente, vai conhecer, mas nem um pouquinho se assemelha. Como eu conto vai ser difícil para vocês encontrarem. Vocês já recorreram por muitos lugares e nunca encontraram quem conta desse jeito.

Em quantos lugares das aldeias já foram? Mas as palavras dos Tupã não vão contar para vocês. E por isso que nosso Criador mostra essas coisas para nós. Cai o raio e queima os corpos deles. Por que numa aldeia o raio matou dois irmãos que estavam rezando? Ficaram calcinados, eles não foram para nenhum lugar, ele queima a nossa alma por nossa falta.

Porque o Tupã não brinca com ninguém, ele não brinca, se ele se levanta não tem nenhum ser humano que fique na frente dele. Porque ele já vem bem armado. Ele tem arma, e os brancos atiram e, por isso, que até está nos alcançando. E nós já não rezamos, dançamos, já não fazemos para que nos escute, é por isso que já matou a muitos e vai matar mais ainda. E vai nos matar mais. Agora mesmo, aquele senhor está doente, e estou fazendo remédio para ele. No meio da conversa, uma mulher chega e fala sobre a doença e morte de uma mulher.

Se a gente reza o nosso Criador escuta nós, se nós rezamos e cantamos com a nossa dança, porque quando ele criou a terra, em cada canto ele deixou 
o kyu kyu. O maior desse mundo, ele é maior que o mundo, ele empurra com seu nariz a terra para que possa ficar grande a terra. Ao contrário as pessoas não iriam caber todas, mas o kyu kyu grande é maior que eles, e maior que o mundo, ele põe as pessoas em cada canto. Ele já pressentiu que nós iríamos ser muitos, porque, se a gente não morre, mas não acaba ali, nosso corpo não cai no chão, nesta terra, eles falam que a terra vai acabar e mentem.

Já falaram para mim isso e vieram me falar três dos nossos antepassados que vai ter coisa ruim nesta terra, mas que não vai acabar, isso é mentira. Nós estamos relembrando dos nossos antepassados, e já não tem pessoas que reza e que cuida pela terra. A nossa reza nos defende; e defende todas as crianças, as árvores, defende todos que estão acima da terra. Para isso o nosso Pai nos deu poder para a gente se defender; mas nós hoje já não levantamos e, por isso, já cai raio por nós, e nos mata; já não fazemos escutar; eles continuam esperando o nosso canto, e nós não rezamos, não temos takua, não temos mbaraka, somente pelo livro dos brancos, somente por ele.

Eles não querem ver as coisas dos brancos, eles querem escutar eles mesmos por nós, porque, se manda um vento forte, vem o dono do vento, vem o dono do vento com o vento, vem o nosso dono com eles. Se vem o nosso Criador e se dançamos, ele pode nos ouvir. E desvia ou acaba com o vento forte, porque o rezador já fez para eles escutarem, e para não cair o raio, e falam para os outros. Os grandes granizos que vocês trazem (os brancos). A reza leva para outros lugares. Os deuses dizem: levantem e leva, uma ou duas vezes depois de rezar já começam a se acalmar, atiram longe.

O dono do vento é quem traz, os deuses. São deles. E por isso que, quando nós rezamos, eles já seguram e não atiram. O nosso criador vem com eles e segura eles, e ali se faz escutar o dono da terra: não atirem mais. Porque tem muita criança que pode se assustar, eles dizem. E agora já não escutam, atiram como eles queiram. Se vier a granizada, a gente se acolher como um velho cachorro. E os crentes entram em suas casas como a orelha de porco, todos juntos porque eles não têm mborahéi (canto deixado pelo Ñanderu). Não tem como os deuses fazer granizada se eles nos escutam.

As granizadas e o vento traz o tupã mesmo. E atiram ou deixam cair como eles quiserem, porque a gente já não se faz escutar para eles ouvirem nós. Tem os 
cantos específicos para cada um deles. Uma vez veio o vento forte aqui, o Airtom estava vindo correndo, e me chamaram lá, e eu estava sozinho, me chamaram e disseram está vindo um vento muito forte, não se assustem, não se assustem não é nada isso, falei para eles. Chamaram-me, todos são crentes, e foi; foi rezar e cantar para eles. Acabou o vento forte, pois a reza é escutada de longe. Já não cai mais, porque eu tenho o canto para isso. Muitos sabem, não um só, os deuses sabem, nosso Pai sabe. Assim, tem o nosso Ñanderu, e ele tem o Pai dele e também tem o Grande. Foi ele quem mandou, e agora já não tem ninguém quem saiba.

Agora já querem tentar viver como os brancos. Sim, querem tentar o jeito de viver dos brancos. E se vamos assim todos, esta terra que estamos pisando não vai nos suportar; vai vir o vento forte e vai tirar do chão, porque esta terra é dos deuses mesmo, e se nós não cantamos mais, se não vamos defender as crianças, então é melhor que nos matem. Nossa reza segura o vento, e por isso o Ñanderu, mesmo que escurece, ele segura as granizadas, o vento forte, ele tem poder para segurar. Porque isso tudo é dos deuses mesmo.

A terra é dos deuses, a nossa vida, todas as coisas eles podem assegurar. $\mathrm{E}$ a reza é deles, eles foram que deixaram para nós; e nós somos o dono da terra, a nossa origem está nesta terra. E depois de nós que nasceram os brancos. Nós que somos parte da terra. Deixou para nós o canto para que possamos defender as nossas famílias e as que não são também, para todos, animais todos as coisas que estão na terra; através da reza nos defendemos. A reza é a favor de todos, porque não tem nada que possa segurar, nem as árvores; se eles quiserem cortar, cortam tudo, as raízes mandam tudo para fora, e sem quiserem levar rapidamente, nos levam porque nós não rezamos mais para que ele possa nos escutar. E se temos o canto e se rezamos, eles seguram e não acontece nada.

Caminhamos com Cantalicio por entre a roça de plantas de remédio que ele fez ao lado da própria casa, roça com plantas do mato. O Ka'aguy (o mato) dá a todos a sua frescura, a sua beleza. Por meio do ka'aguy, presta atenção nos pássaros, sem eles nós não temos comida. Ka'aguy está para todos, porque ali tem muitas variedades de alimentos, parece que nós não temos comida, mas a comida nunca falta. Tem guavira pytã, yvaũ, pindo aju, tem tajyva, tem yvyra jepiro'i, yvyratĩ, todas as classes de árvores têm no mato, porque o mato defende a nós todos. E pelo mato que temos nossos remédios. Antigamente não tinha hospital, 
nos vivíamos dos remédios tradicionais, os nossos antepassados usavam os remédios tradicionais e, hoje em dia, não usamos mais o nosso remédio tradicional. As crianças nascem no hospital porque os brancos têm salário, e eles precisam que a gente aumente a cada dia, para que eles possam ter melhor salário, por isso precisamos ir ao hospital.

O remédio tradicional tem de tudo, olha este, este marinero'i é para o ferimento do cerrado. E bom para tosse seca. O mato serve para nós, olha o ka'aguy pequeno, ali tem muitas plantas medicinais. Tem também, antigamente, algumas mulheres no período da menstruação não paravam, pois e tem o karaguara'i e tem a kangorosa, e põe com ele a carcaça do karumbe, consome só um pouquinho até meio litro e já para a menstruação. E agora já ninguém sabe nada.

Tem também remédio para o coração. Na casa da minha filha, tem cedro, tem que tirar o que está na direção da saída do sol, um quarto da raiz e depois já tem que cortar, como a mandioca, bem cortado. Tem que ferver e depois tomar. Antes de tomar um litro, já tira a dor e já não sente nada. Esse remédio já não tem mais quem sabe, já não tem mais. Olha, eu plantei o kurupirembo, se a gente sente câimbra tem que passar. Estas coisas plantei depois que já não tinha mais mato. Eu trouxe do mato, e já está acabando pela queimada que se faz no mato.

Este é ysypo mil homens, se você não sente mais fome tem que tomar no tereré, olha o cheiro dele. Eu plantei. Tem que trazer só a raiz e plantar. Aquele é para o umbigo das crianças, antigamente as nossas mães cortavam o umbigo e curavam com a pele desta planta. Tem que plantar a pele dele. Tem que fazer assim e usar só um pedacinho. Tem que secar como um pó. Olha, eu plantei o cedro, e este se chama kokũ, que é a comida do jaku (jacutinga), ele é refrescante para o estômago também, faz você ter apetite. Eu plantei porque já não tem mais pelo mato, e quem relembra de isso já não tem mais. Este que eu plantei é um cedro, ela refresca o ambiente. Ele é muito importante e serve para a dor do coração. 
Foto: Pés de conhecimento ${ }^{7}$. Porto Lindo/Yvy Katu.

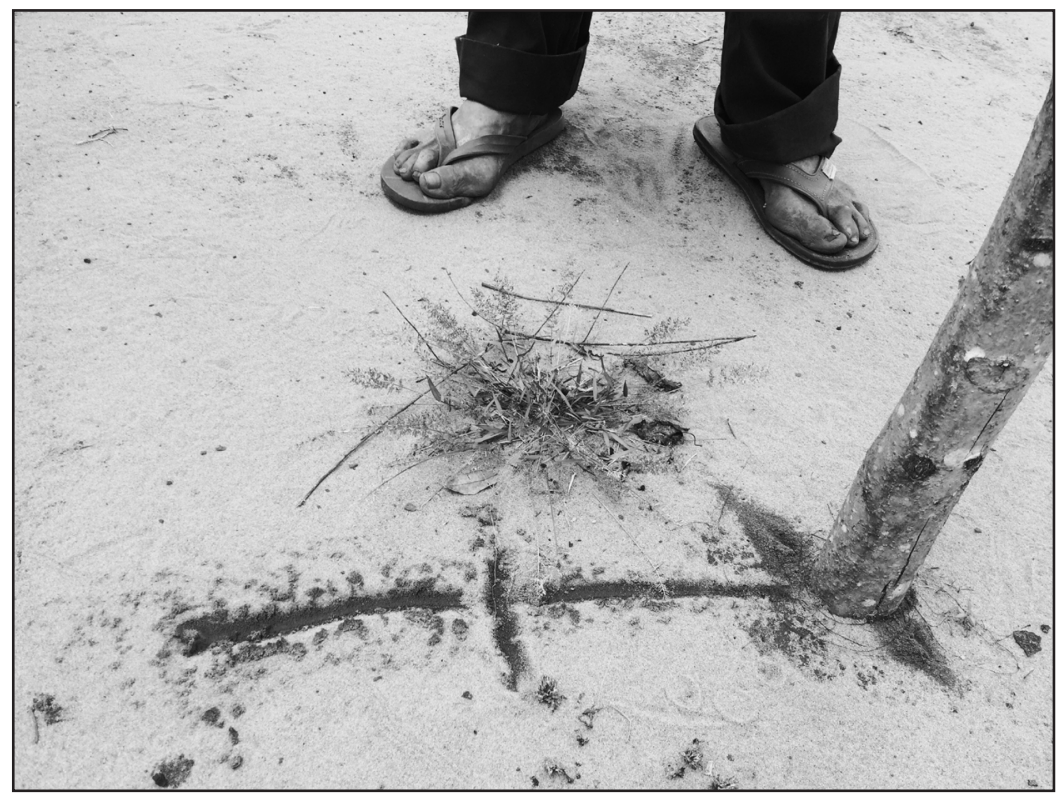

Foto: Acervo pessoal de Yan Chaparro, 2018.

Do cedro nasce a cigarra, onde fica goteando a água embaixo da terra, ele nasce. Faz dois anos e seis meses que estou aqui, e as plantas crescem rápido, os ipês que plantei são bons para dor de dente, as que eu plantei não têm nenhum que secou. Para que, quando eu morrer, que fique e falem é o fulano que plantou. Este é guavirami, que serve para diarreia. Esta planta é a sapirangy; se no mato mordesse você uma cobra, a casca tem que cortar em pedaços e engolir, se engoliu já não vai morrer facilmente, porque o veneno não espalha no corpo. E por isso que nos faz falta o mato, já não temos mais nosso remédio neste matinho. Já não tem mais quem conheça os remédios, já não tem mais. Já se converteram para outra igreja. Eu planto esses remédios.

Existe rezas para os donos do mato. Até os donos do mato vão ficar felizes com a nossa reza, são deles também, eles nos ajudam, só que eles não têm sabedoria e tem medo dos Tupã, e a gente já não tem quem reza. Estamos nós

\footnotetext{
${ }^{7}$ Imagem que retrata os pés de Cantalicio Godoi junto ao pé de Cedro que ele mesmo plantou. Fotografia que foi registrada no momento quando ele faz explicações sobre a importância do Cedro como remédio para os Ñandeva/Avá Guarani.
} 
acabando. É porque Tupã fez muitas coisas, que os nossos deuses, eles nos abençoam porque plantamos de novo algumas árvores e manda chuva para que possa crescer forte. Aqui onde estou, já tem mais um pouquinho de mato.

Eu quero que entregue essas coisas que eu falo para cada professor e professora, para que tenham na escola, para que não fiquem seguindo os crentes, pelo contrário vai nos queimar a todos. Se a gente seguir os crentes, a gente vai queimar, porque a gente não reza mais.

Aqui a minha filha Ermecinda, ela dança para as crianças, ensina eles porque ela, por meio tentou ser crente, mas se saiu mal também. O Ailton já está quase indo para os crentes, mas veja como eles estão vivendo agora, mora em casa dos outros, não serve para nada. Não está mais tranquilo, e essas coisas não são boas? Vivemos bagunçados, nem o nosso Deus já não escuta nós. Já andamos como um cachorro pela rua. Se consegue se alimentar, come ou, do contrário, não tem nada. Estas coisas eu sinto, mas fico quieto; eu não conto para ninguém, porque não vão confiar em mim. O que vai conhecer este índio velho? Vão falar de mim. E já começa a abrir a bíblia, e aí está que vão falar. Mas a nossa fala passa por cima deles porque nossa palavra está com o Tupã. Eu sempre estou pronto para quem me necessita para ajudar com ou sem a minha família, para isso eu estou.

Como o fogo, está ele na nossa frente e serve para todos. Se está frio, serve para qualquer cachorro, qualquer galinha se esquentar, porque ele está na frente desde o começo. Ele não se apaga, nossa mãe e nosso pai, nós pedimos a ajuda deles, e levantamos a mão por eles, e vamos só até ali, a partir dali o nosso Ñanderu faz de nós o yrupẽ, vai ficar do lado do caminho com os bichinhos pertos, vai pagar a sua culpa por levantar a mão para sua mãe, dali que Tupã se levanta e faz cair o raio por ele. E depois o Tupã se levanta e faz de você aguara, chora por onde foi a sua casa; pagando a sua culpa. O dia que você pagou toda a sua culpa ali recém leva você. Tem que pagar primeiro a sua culpa na terra. Então estas coisas já ninguém sabe mais, mas os que falam por falar, tem muito por aí.

O fogo também nos defendia sempre. Tem que passar pelo corpo como remédio com a gordura do sucuri, ele é um animal forte. Com a gordura da tartaruga se você passa como remédio pelas crianças, elas sempre ficam sã, porque esses são bichos que dá frescura, que dá beleza e fica tranquilo. Eles moram na água por isso que a gordura deles nos serve como remédio e, hoje em dia, já não 
tem ninguém que saiba isso. E bom para nós o nosso fogo dentro de casa, porque eu até hoje, como pirekái (mandioca assada no fogo), ando como eu sei e estou com saúde. E continuo trabalhando.

As crianças querem tocar o fogo porque nós, quando crescemos, somos ignorantes não sabemos nada, e é por isso que mexem com o fogo. Porque o fogo dói prá nós, as crianças querem mexer pensando que não vai doer. As que começam a falar, as que engatinham, as que recentemente caminham eles querem mexer no fogo.

Mas, quando crianças, a gente vê Tupã. Olha, o Tupã surge todas as coisas. Tupã se quiser vir como gua'a, ele vem. Se quiser vir como arua'i, ele vem como ele quiser, porque ele não tem o nosso sangue. Se ele quiser se levantar como loros, ali ele vem. Mas ele traz o raio. Se ele atira raio, castiga a terra, e nós dizemos está relampeando. As crianças que não tem pecado também vê. Porque do Tupã surge todas as coisas, só que são pássaros. Quando eles mandam, mandam pelo pássaro através do raio. E quando dizemos oñembiara nós dizemos overa (a luz do raio).

As crianças podem ser de tudo, mas não pode contar de qualquer jeito. Porque lá está o Ñanderu guasu, que faz o batismo das crianças. Porque quando o Ñanderu vai fazer o mitã karai (batismo da criança), o nosso Ñanderu fala prá ele. Pode ter o nome qualquer. Olha ali tem o Tumái, esse, o nome dele, é o Kuñamba. De ali e Kuña karupoty o nome dela, nome tradicional. Mas que só de nós não podemos pôr nomes, porque tem quem manda.

Tupã Veraju sou eu. As famílias que não têm nome tradicional nem vão para as rezas tradicionais, e possui um nome qualquer, isso não pode. Então quando vai ter seu nome, o Ñanderu tem que pôr o nome, e deve vir de cima e não deve ser de qualquer forma. Todos os pássaros foram nossos antepassados. Todos nossos antepassados. Se a terra vai acabar, o nosso Ñanderu diz: vocês precisam dançar porque a terra vai desaparecer. E eles não acreditam, e o nosso Ñanderu dança, só quem acredita dança dois meses, come rora, tangu'i, caldo de peixe, somente. Isso que deveria acontecer.

Todos os pássaros que tem na terra, lá com Tupã tem todos eles. O tukã sa'yju se baixar aqui o Tupã já vem pra dançar. Todos os que estão com seu corpo limpo vai levantar. Tupã fala, vou sacar o meu caraguatá, dali ele já saca e vem, já vem o 
caminho e, quando fica na terra, eles já se retiram. E depois quem ficou, ele fez deles pássaros. Todos os pássaros que estão na terra são nossos antepassados. Todos os pássaros. Taguato hovy, gaviota, tingasu'i, todos eles são das costas das grandes águas, ali não tem mato, e nosso Ñanderu mandou para nós para se procriar, porque aqui tem comidas para alimentar a seus filhos, lá não tem; somente o nosso Pai quem dá os alimentos pra eles. Faz para eles kupi'i cupim; presta atenção, quando vem o taguato, os cupins voam daqui para lá, também voa o ysa (formiga sau) em outubro e para suas comidas. Os pássaros comem os cupins, e protege a gente.

Como eu já disse. O vento serve para todos. Olha como que está furado a nossa pele, toda a nossa pele tem furinho, e o vento que nos sopra, refresca o nosso sangue; nós comemos muitas coisas, ajuda o nosso coração e todos os pássaros; o vento é quem ajuda a viver. Nesse lugar (Yvy Katu), vai germinar novamente as árvores; os não indígenas tiraram tudo de nós, pindó, guavirami, todas as árvores eles derrubaram, tiraram fora a raiz e queimaram tudo. Para virar dinheiro. Mas agora vai ficar muitos remédios para nós e, daqui uns 20 anos, vai ficar cheio, já estamos apertados aqui.

A terra serve para todos, porque as crianças vão nascendo, e nunca vamos sumir da terra, vamos ficar mais cheio. Se a árvores ficarem, ficam pra nós. E os brancos usam isso, fazem tábua para vender entre eles e só para ter dinheiro, mas nós não somos assim. Nós cuidamos do mato para que não acabe, olha lá, fazendo ka'aguy como se dizia, mais para baixo tem Barrero antigo, eu chamava de Barrero Hũ, o Barrero e quem come os bichos, e tem terra preta aí e eles comem da terra. Tem uma sanga, aí desce até mborevi, vários animais, esse é o Barrero Antigo. Variedades de animais como a onça se juntam aí. Em Yvy Katu.

Antigamente já tinha nós aqui. Tinha o finado Nolasco, lá no canto, ali tinha dom Solano, a sua esposa chamava-se dona Ângela; lá na descida, morava Rondón, ainda vive; tinha muito palmito. São famílias que estão aqui desde muito antigamente. Lá morreu Henrique, eu conheci ele, aqui morava no lugar do Yvu, a casa de dom Máximo. Lá tinha casa de reza, ele mesmo tinha. Também tinha dom Solano. Também Nolasco tinha a casa de reza. Antigamente só ali se preparava a chicha. A chicha era feita do Avati Morotĩ, Pindo Aju, Guavira Pytã.

E o guavira pytã é feito em um recipiente, colava com um mantel para que não fique sujo, e depois na bateia feito do cedro. Isso era a nossa bebida, alimentávamos 
raras vezes da comida dos brancos. E por isso que nossos parentes viviam 120 anos, 115, 125 anos, mesmo velho caminhavam bem. E agora? Entrou entre nós a enfermidade, as coisas dos brancos; o suicídio, tomou veneno, se matou e já vai, está nos matando e nós nem sabemos, pensamos que só sucedeu por suceder.

Isso tudo que eu falo vem de Tupã. Precisa que isso se ensine nas escolas. Para que as crianças venham aqui para me ouvir. Tenho um neto que está com diarreia e tenho que fazer assim (foi buscar), este é o pindo'i. parece mesmo o nosso sangue, este é o remédio para dor de ventre.

O nosso Tupã está onde nasce o sol. O nosso Ramõi fez o Tupã do orvalho. Tem luz no nosso caminho, na nossa vida e, quando tem escuridão, tem luz no nosso coração, do contrário não vamos ter respeito. Nós temos a nossa própria luz e está em nosso coração. E o Tupã cuida de isso. O nosso espírito vive acima, não está no corpo, porque o nosso corpo está sujo. Porque comemos muitas variedades, e a gente faz muitas coisas. Porque o espírito não pode, tem que cuidar da sua fala, e tem que prestar atenção do seu corpo. Quem esta grávida tem dois espíritos; um que está débil e outro, o espírito da mãe, mas eles não estão grudados no corpo, só cuida, ilumina, presta atenção no nosso corpo. Do contrário, o que a gente não enxerga não respeitamos. Todos que estamos na terra, se estamos na escuridão, os espíritos não vão respeitar nós. O nosso Ñanderu põe uma luz para nós para quem não queira respeitar, possa respeitar.

Foi Tupã que me deu a reza. Foram eles quem vieram e me levaram para rezar lá no lugar onde está Tupã. Fui no meu sonho, mas nosso corpo fica. A nossa carne não pode levar, o nosso espírito é quem vai lá pra rezar. Foram eles (o Tupã e os deuses) quem deram para nós a reza. E me veste para não esquecer. Também é assim com os remédios. Quando alguém está doente, eles vêm e dizem para mim que vão precisar de mim e fique atento e espere; então eu já sei que classe vai vir, quem precisa de mim vai me visitar. Os Tupã mesmo são as que vêm e avisa antes mesmo. manda ferver tal remédio para eles. E faço como eles mandam. Tem o pipi que é um remédio para dor de cabeça com a gordura do teju (lagarto), aperta com o remédio onde sente a dor e, hoje dia, nem o teju já não existe. Então fica difícil saber esses remédios só se for os tupã quem dá para nós.

Os Tupã possuem alma, quando a gente tem uma má intenção eles já sabem, diz para eles e vão querer castigar. Quando a gente sonha matando uma 
cobra grande. Se a cobra for grande, significa traição. Porque a cobra nunca vai te morder quando estiver na sua frente. E se você mata, é seu espírito quem mata a cobra. Nós a matamos com madeira, mas o Ñanderu só manda um raio ou uma luz. Você pode rezar por mim para ver como é que estou? (Eliezer). Posso sim. (A reza por Eliezer).

Hoje na terra estamos indos todos mal. Já não somos iguais na terra. Muitas coisas que os não indígenas usam já estão usando nossos parentes indígenas. Até hoje em dia, ainda não vi aquela planta, e eu vivo de acordo a minha sabedoria. A causa de usar essa planta faz muitas coisas ruins; se suicida, faz por ele. O não indígena também se suicida, e ele os Tupã tira deles a vida, se os brancos se atiram aparentemente dos prédios, são eles mesmo quem tiram as próprias vidas deles mesmo.

Só quem se suicidou fica aqui, o nosso Ñanderu não acolhe, fica na terra; só depois de cumprir algum castigo que o nosso Ñanderu leva, só depois de pagar tudo e sem fazer nada de mal, do contrário fica aqui na terra porque não tem ninguém quem pode enfrentar nosso Ñanderu, são eles quem dominam a terra. São eles quem mandam. Cada ano eles fazem crianças do orvalho, e nós, de outro jeito porque comemos, insurjamos a nossa boca e o espírito não se acerca em nós, só fica cuidando perto de nós.

Para as crianças que vão nascer e que estão crescendo, vai ter tranquilidade para eles? (Eliezer). Vai ter sim, ainda vai ter, não temos coisas muito ruins na terra, só que nós andamos mal porque não rezamos mais. E por isso que a nossa família se suicida. Olha para mim, se eu não me comportar bem não iria ficar velho do jeito que estou. Porque eu sempre levo presente, mesmo que vivo sozinho tenho que rezar antes de dormir.

Os Tupã ainda traz para mim, ainda diz para mim como devo contar. E também não diz para qualquer um. Entre os não indígenas, não tem ninguém que crê em Tupã, eles não creem verdadeiramente. Eles acreditam mais no dinheiro, não se lembram mais dos nossos Ñanderu, e é por isso que acontece qualquer coisa ruim no caminho, na casa deles, na cama, qualquer coisa. São egoístas e não se lembram do nosso Ñanderu, só fica preocupado pelo dinheiro que guardou. Não se lembram dos Ñanderu e do Tupã. E esses sabem de isso, do nosso pensamento, nós vivemos nas mãos deles, por um espelho grande eles nos enxergam, cada um 
de nós, como nós vivemos, e por isso que eles não respeitam os não indígenas, derruba as suas casas, vêm alagamento, granizada, até sismo.

Nosso mundo ainda é seguro. Ainda está seguro, mas o que falta para nós é rezar, e estas coisas o Ñanderu mesmo mostrou para mim, e é por isso que estou contanto porque, se for só da minha conta, não poderia contar. Só porque o Ñanderu mostrou para mim que sei. Porque se eles não mostram para mim, eu não posso contar. São eles mesmo que estão comigo.

A nossa dança e reza é bom que ensine às crianças, porque eu já não estou enxergando muito bem; tem kotyhu, jeroky, a chipa que se fazia com o pariry. Hoje em dia, ninguém faz mais, e as crianças precisam comer e beber a chicha, e a chipa cozida na cinza. Isso temos que ensinar também para as crianças.

Então hoje as pessoas, já não estamos indo pelo caminho certo. O Ñandejára mesmo está fazendo eles se suicidarem. E eu não estou sozinho aqui, olha as flores, somente borboletas ao meio-dia, pássaros, o beija-flor que suga a essência da flor, eles ficam felizes com tudo isso, para mim é uma felicidade, e eu respeito eles. O mato tem dono, a água tem vários que cuidam, e eles moram na água, mbói guasu, jagua marito; e tem dono da água que a gente não vê, que cuida deles e também do mato, cada um tem o seu dono, o vento tem o seu dono também.

A gente não a vê os donos, só tem reza para eles e isso também é um espírito, eles cuidam de dia e noite. e é por isso que o mato é abençoado e é bonito. As plantas têm o seu dono. Nós falamos que temos o nosso dono, o Santo Isidro é o dono da roça, que cuida das roças, quem vem de lá perto do Ñanderu, desde lá, ele cuida, ele vem também, mas que nós não vimos ele. Já tem pouca pessoa que conhece.

Tem reza para acalmar aos brancos? (Eliezer e Yan). Tem, se a gente não tivesse a reza para lutar e para acalmar os brancos, não estávamos resistindo até hoje. Porque você (Eliezer) deve lembrar quando os Tupã vieram deste lado e fez retroceder os brancos; quando os brancos tentaram reagir, o Ñanderu trancou eles com o vento forte e fez os brancos retroceder. Porque não tem ninguém que possa se impor contra o Ñanderu. São os Tupã e o Ñanderu quem manda. Os brancos pensaram e fizeram muito mal, mas os Tupã saíram na frente dos brancos e, então, não aconteceu nada (durante o momento de conflito na ponte do rio Iguatemi durante a retomada de Yvy Katu). 


\section{REFERÊNCIAS}

ALBERT, B; RAMOS, A. (Org). Pacificando o branco: cosmologias do contato no norte amazônico. São Paulo: Editora Unesp, 2002.

DERRIDA, J. Margens da Filosofia. Editora Papirus: Campinas, 1991.

DELEUZE, G.; GUATTARI, F. Kafka: por una literatura menor. México: Ediciones Era, 1978.

KOPENAWA, D.; ALBERT, B. A que do céu: palavras de uma xamã Yanomami. São Paulo: Editora Companhia das Letras, 2015.

LATOUR, B. Jamais Fomos Modernos. 4. Reimp. Rio de Janeiro: Editora 34, 2008.

TAUSSIG, M. O diabo e fetichismo da mercadoria na America do Sul. São Paulo: Editora Unesp, 2010.

TAUSSIG, M. Xamanismo, colonialismo e o homem selvagem: um estudo sobre o terror e a cura. São Paulo: Editora Paz e Terra, 1993.

\section{Sobre os autores:}

Yan Leite Chaparro: Psicólogo, pesquisador, mestre e doutorando em Desenvolvimento Local pela Universidade Católica Dom Bosco (UCDB). Integrante do Grupo de Pesquisa Estudos Críticos do Desenvolvimento/CNPq, do Laboratório de Humanidades (LabHu) e do Grupo de Estudos Filosofia Ameríndias/OuVir. E-mail: yanchaparro@gmail.com

Josemar De Campos Maciel: Professor do Programa de Pós-Graduação Mestrado e Doutorado em Desenvolvimento Local da UCDB, e do Programa de Pós-Graduação em Desenvolvimento Territorial Sustentável Erasmus Mundus/SETED. Coordenador do Laboratório de Humanidades (LabHu ). E-mail: maciel50334@yahoo.com.br

Eliezer Martins Rodrigues: Indígena da etnia Avá Guarani, cientista social, mestre em Educação pela UCDB e professor da escola indígena polo do território Porto Lindo (Jakarey) Yvy Katu, no munícipio de Japorã, Mato Grosso do Sul, Brasil. E-mail: eliezer2016martins@gmail.com

Arnulfo Morinigo: Professor de Guarani, filósofo e graduando em Ciências Sociais pela Universidade Federal da Grande Dourados (UFGD). E-mail: arnulfomorinigo@gmail.com

Recebido em 2 de julho de 2018

Aprovado para publicação em 10 de outubro de 2018 